\title{
Formation and Changes of Humic Acid Properties during Peat Humification Process within Ombrotrophic Bogs"
}

\author{
Oskars Purmalis, Maris Klavins
}

Department of Environmental Sciences, University of Latvia, Riga, Latvia.

Email: maris.klavins@1u.lv

Received March 12 ${ }^{\text {th }}, 2012$; revised April 13 $3^{\text {th }}, 2012$, accepted April 30 $0^{\text {th }}, 2012$

\begin{abstract}
Studies of the living organic matter humification process are essential for understanding the carbon biogeochemical cycle. The aim of this study is to analyze relations between the properties of peat, peat humic acids and peat humification degree. The analysis has been done on samples of humic substances extracted from peat profiles in two ombrotrophic bogs and relations between peat age, decomposition and humification degree, botanical composition and properties of peat humic acids (elemental, functional composition) were studied. The found variability of peat properties is less significant than differences in the properties of peat-forming living matter, thus revealing the dominant impact of humification process on the properties of peat. Correspondingly, composition of peat humic acids is little affected by differences in the composition of precursor living organic material.
\end{abstract}

Keywords: Peat; Humic Substances; Humic Acids; Humification

\section{Introduction}

In the carbon biogeochemical cycle, the transformation of living organic matter into refractory part of organic matter (humic substances, such as humic acids, fulvic acids, and humin) or humification is of key importance. Humification can be defined as the transformation of numerous groups of substances (proteins, carbohydrates, lipids etc.) and individual molecules present in living organic matter into groups of substances with similar properties (humic substances) [1]. Humification plays an important role in the diagenesis of fossil carbon deposits [2]. Humification is a sum of very complex processes including degradation and synthetic reactions, but also considering the high variability of environmental conditions under which living organic matter decays, slow pace of humification reactions and large number of structural differences of the organic molecules composing living organic matter. It can be supposed that humification conditions may have an impact on the structure and properties of refractory intermediate transformation products of living organic matter-humic substances. From this perspective, it is important to study humification processes in a relatively homogeneous and stable environment, for example, bogs to reduce the impact of natural environmental variability.

\footnotetext{
"The research was financially supported by ERAF, the project "Innovation in Peat Studies for Development of New Applications". No: 210/0264/2DP2/2.1.1.1.0/10/APIA/VIAA/037
}

Peat is a light brown to black organic material, which is formed under waterlogged conditions from the partial decomposition of mosses and other bryophytes, sedges, grasses, shrubs, or trees [3]. The interest in peat properties is growing, as peat is a substance that supports and influences bog and wetland ecosystems, while peat profiles can serve as "archives" indicating conditions in past environments $[4,5]$. Significant amounts of organic carbon are stored in the form of peat. Therefore, peat reserves play a major role in the carbon biogeochemical cycling, which is of key importance in the context of the ongoing process of climate change [6,7]. Industrial and agricultural uses of peat are growing [8,9], and significant amounts of peat are mined industrially. Considering this, there is an increasing interest into studies of peat properties and their diagenesis. Humification in peat has been taking place in very different conditions both geographically (from tropical regions to Arctic environment) and temporally (historically peat development can last for many thousands of years). During peat formation even at one particular site, significant changes in vegetation, temperature, amount of precipitation and, correspondingly, in the bog hydrological conditions and land use in the basin of wetland [10-12] could have happened. As a result, we can expect not only to understand changes in the properties of peat humic substances but also to identify molecular descriptors of organic matter diagenesis process. Notwithstanding the importance of this sub- 
ject, relations between the properties of peat (especially in full peat profiles) and those of peat humic substances have been studied comparatively little, just in a few studies [12-14].

The aim of this study is to analyze relations between the properties of peat, peat humic acid and peat humification degree.

\section{Materials and Methods}

\subsection{Site Location}

In-depth study of peat composition, humification degree and peat humic acid properties was carried out in two ombrotrophic bogs located in the central part of Latvia (Figure 1). Full peat profiles were obtained and cut into 5 -cm layers for analysis of peat properties and isolation of humic acids. The analysis of botanical composition was performed microscopically, using a Carl-Zeiss binocular microscope, thereby determining the decomposition degree [15].

\subsection{Isolation of Peat Humic Acids}

HAs were extracted and purified, using procedures recommended by the International Humic Substances Society (IHSS) [16].

\subsection{Analysis of Peat and Humic Acid Properties}

The ${ }^{14} \mathrm{C}$ dating was done at the Institute of Geology of the Tallinn Technical University (Estonia). Carbon, hydrogen, nitrogen and sulphur concentrations in the peat and humic acid samples (elemental analysis of $\mathrm{C}, \mathrm{H}, \mathrm{N}, \mathrm{S}$ ) were determined by combustion-gas chromatography technique, using an Elemental Analyzer Model EA-1108
(Carlo Erba Instruments). Ash content was measured after heating $50 \mathrm{mg}$ of each peat sample at $750^{\circ} \mathrm{C}$ for $8 \mathrm{~h}$. Elemental composition was corrected considering the ash content, and the oxygen amount was calculated as a difference. Elemental analysis was used in order to calculate the elemental ratios, degree of oxidation $\omega$ (1) [17] and index of hydrogen deficiency $\phi(2)$.

$$
\begin{aligned}
& \omega=(2 \mathrm{O}+3 \mathrm{~N})-\frac{\mathrm{H}}{\mathrm{C}} \\
& \varphi=\frac{(2 \mathrm{C}+2)-\mathrm{H}}{2}
\end{aligned}
$$

Atomic ratios were calculated from elemental analysis, using the Equations (3), (4):

$$
\begin{aligned}
\mathrm{O} / \mathrm{C} & =\frac{(\mathrm{Mc} \cdot \mathrm{O} \%)}{(\mathrm{Mo} \cdot \mathrm{C} \%)} \\
\mathrm{H} / \mathrm{C} & =\frac{(\mathrm{Mc} \cdot \mathrm{H} \%)}{\left(\mathrm{MH}_{\mathrm{H}} \cdot \mathrm{C} \%\right)}
\end{aligned}
$$

where $\mathrm{M}_{\mathrm{X}}$ is the element molecular mass, and $\mathrm{X} \%$ is percentage of the element in the sample.

UV/Vis spectra were recorded on a Thermospectronic Helios $\gamma$ UV (Thermoelectron Co) spectrophotometer in a 1-cm quartz cuvette. The ratio $\mathrm{E}_{4} / \mathrm{E}_{6}[18]$, i.e. the ratio of absorbance at 465 and $665 \mathrm{~nm}$, was determined for 10 $\mathrm{mg}$ of humic acid solutions in $10 \mathrm{ml}$ of $0.05 \mathrm{M} \mathrm{NaOH}$.

\subsection{Humification Degree (according to [19] and Modified by [20])}

$1.00 \mathrm{~g}$ of peat sample was treated for $1(1 / 2)$ hrs with 25 $\mathrm{ml}$ of $8 \% \mathrm{NaOH}$ in $25 \mathrm{ml}$ plastic tube in a boiling water bath $\left(95^{\circ} \mathrm{C}\right)$ and filtered. $12.5 \mathrm{ml}$ of the filtrate were

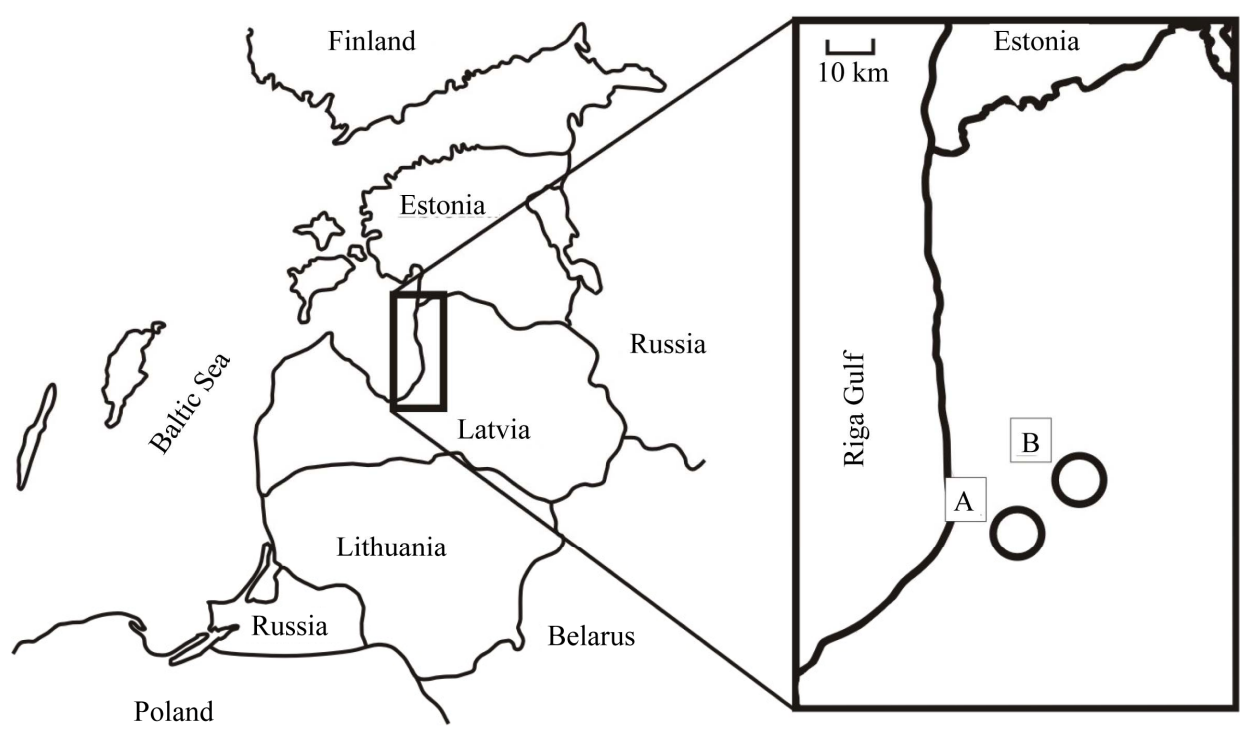

Figure 1. Sampling sites: A-Dzelve bog; B-Eipurs bog. 
diluted to $100 \mathrm{ml}$ and absorption was measured at 540 $\mathrm{nm}$. The peat humification degree was expressed as absorption at $540 \mathrm{~nm}$.

\subsection{Carboxylic Groups and Total Acidity}

An automatic titrator TitroLine easy (Schott-Geräte $\mathrm{GmbH}$ ) was used for measuring carboxylic and phenolic acidity of each HA. The known Ca-acetate method [16], based on the formation of acetic acid, was used for determining the total number of carboxylic groups. HAs $(20 \mathrm{mg})$ were weighed into a $100 \mathrm{ml}$ Erlenmeyer flask, $10 \mathrm{ml}$ of the 0.2 $\mathrm{N}$ calcium acetate solution were added and mixed under $\mathrm{N}_{2}$ for 24 hours. Samples were potentiometrically titrated to $\mathrm{pH} 9.0$ with $0.1 \mathrm{M} \mathrm{NaOH}$. To estimate the total acidity, $20 \mathrm{mg}$ of humic acid, were dispersed in $10 \mathrm{ml} 0.1 \mathrm{M}$ $\mathrm{Ba}(\mathrm{OH})_{2}$ solution, which was then shaken overnight under $\mathrm{N}_{2}$ atmosphere, filtered and washed with water. The filtrate, together with the washing solution, was potentiometrically titrated with $0.1 \mathrm{M} \mathrm{HCl}$ down to $\mathrm{pH} 8.4$ under $\mathrm{N}_{2}$ flow.

\subsection{Hydrophobicity}

Hydrophobicity of humic substances was characterized by their distribution between water and polyethylene (PEG) phases (PEG 20000, Fluka) [21] as distribution coefficient $\mathrm{K}_{\text {PEGW }}$ (analogous to octanol/water distribution coefficient- $\left.\mathrm{K}_{\mathrm{ow}}\right)$. The $10 \%$ PEG- $10 \%\left(\mathrm{NH}_{4}\right)_{2} \mathrm{SO}_{4^{-}}$ $\mathrm{HA}-\mathrm{H}_{2} \mathrm{O}$ systems were prepared by mixing $2 \mathrm{ml}$ of $30 \%$ PEG solution with $2 \mathrm{ml}$ of ammonium sulphate solution and $2 \mathrm{ml}$ of $\mathrm{HA}(2 \mathrm{mg} / \mathrm{ml}$ in $0.05 \mathrm{M} \mathrm{NaOH})$. The mixtures were shaken for $10 \mathrm{~min}$. After complete phase separation, $1 \mathrm{ml}$ was taken from each phase and diluted by 10 times in $0.05 \mathrm{M} \mathrm{NaHCO}_{3}$. Then the absorbances at 465 $\mathrm{nm}$ were measured on a DR/2000 spectrophotometer (Hach Co). The distribution coefficients were calculated as follows: $\mathrm{K}_{\mathrm{PEGW}}=$ absorbance at $465 \mathrm{~nm}$ of the top (PEG-rich) phase/absorbance at $465 \mathrm{~nm}$ of the bottom phase.

\subsection{Fluorescence Spectra}

Fluorescence spectra were recorded, using Perkin Elmer LS 55 fluorescence spectrometer, on aqueous solutions of each sample at a concentration of $25 \mathrm{mg} / \mathrm{L}$, adjusted to pH 7 with $0.5 \mathrm{M} \mathrm{HCl}$. Emission spectra were recorded (scan speed $500 \mathrm{~nm} / \mathrm{min}$, with slit $10.0 \mathrm{~nm}$ over the wavelength range of 380 to $650 \mathrm{~nm}$ ) at a fixed excitation wavelength of $350 \mathrm{~nm}$. The ratio of fluorescence intensity at $460 \mathrm{~nm}$ to intensity at $510 \mathrm{~nm}\left(\mathrm{I}_{460} / \mathrm{I}_{510}\right)$ was used, as previously suggested by [22], as a humification indicator.

\subsection{Data Treatment}

Statistical analyses were performed using SPSS 16 Soft- ware. The correspondence of the obtained data to the normal distribution was checked with the KolmogorovSmirnov tests. In further analysis, non-parametric methods were used. Relationships between different characteristics were assessed by Spearman's rank correlation coefficients. In all cases the significance level was $p=$ 0.05 .

\section{Results and Discussion}

\subsection{Peat Composition and Their Changes}

Peat humification process and development of peat humic acids were studied in the peat profiles from two heterogeneous ombrotrophic bogs in Latvia.

The results of the paleobotanical investigations (botanical composition, pollen analysis) indicate both differences and similarities in the development and peat properties of the studied bogs. Dzelve Bog has been formed due to paludification of sandy ground as result of groundwater level increase and wet conditions during the small depression after the Ice Age. A raised bog cotton grass peat layer covers the sandy bottom, overlaid by pinecotton grass peat. The upper part of peat section is represented by a $3.2 \mathrm{~m}$ thick Sphagnum fuscum peat layer with a decomposition level $9 \%$ to $17 \%$ (Figure 2). The botanical composition of most of the bog is relatively heterogeneous: Sphagnum fuscum (60\% - 75\%), Eriophorum vaginatum (10\% - 15\%), Sphagnum rubellum (10\% $15 \%)$ and dwarf shrubs $(10 \%-15 \%)$.

The botanical composition of Eipurs Bog is completely different, although it is of a similar origin (Figure 3). The lowest part of Eipurs Bog is formed by fen woodgrass peat, Нypnum and sedge-Hypnum peat (Figure 3), and these layers are covered by transition type wood peat. The upper part is represented by a $3.45 \mathrm{~m}$ thick layer of raised bog peat of different types and decomposition degrees. For example, well decomposed $(40 \%-48 \%)$ pine-cotton grass peat occurs at the depth interval of 1.18 - $1.39 \mathrm{~m}$ (Figure 3). Although these bogs are located comparatively close to each other (distance $12 \mathrm{~km}$ ), their local conditions for peat formation have been different.

Basic peat properties were analyzed, using peat elemental (C, H, N, O, S) composition. The elemental composition of the studied peat cores are summarized in Figure 4, Table 1. The ash contents in the studied bogs range between $0.30 \% \pm 0.05 \%$ and $6.10 \% \pm 0.05 \%$, with an average content of $1.8 \pm 0.05$. The $\mathrm{C}$ concentrations range from 40 to $55 \%, \mathrm{H}$-from $5.4 \%$ to $6.7 \%, \mathrm{~N}$-from $0.5 \%$ to $1.5 \%, \mathrm{~S}$ - from $0.2 \%$ to $1.7 \%$ and $\mathrm{O}$-from $38 \%$ to $49 \%$. The elemental composition of peat in Eipurs Bog is comparatively variable and reflects changes in the peat decomposition degree and peat types. $\mathrm{C}$ concentration in peat is increasing starting from the depth of $1 \mathrm{~m}$ up to the level of $53 \%$ and then again decreasing. $\mathrm{H}$ concentrations 


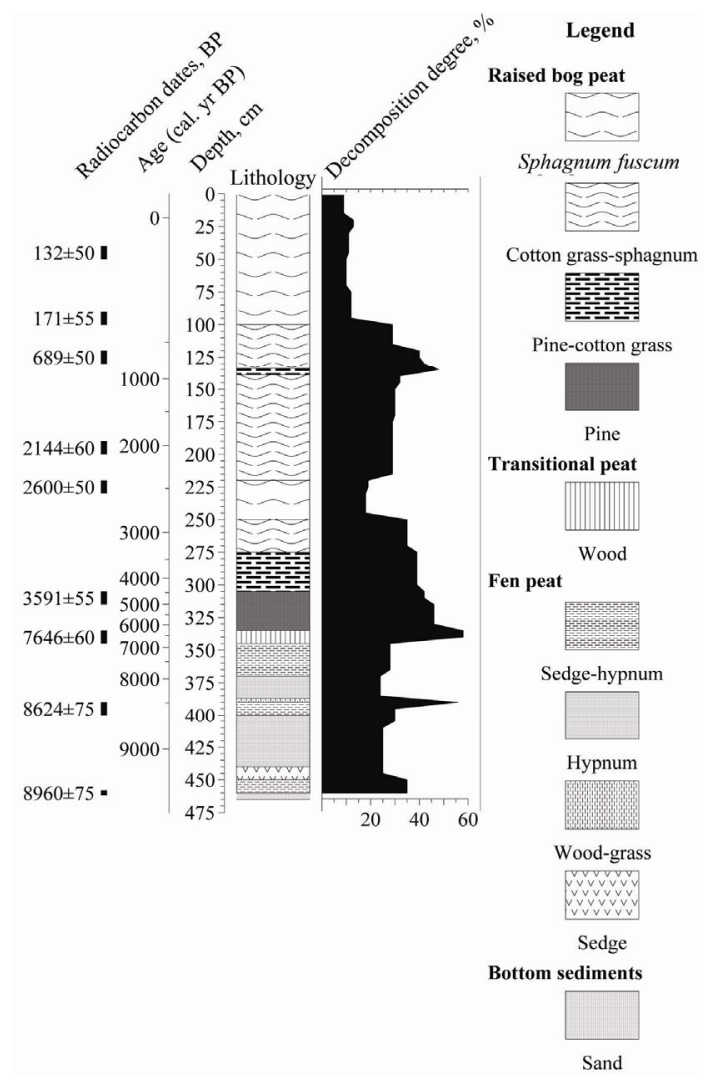

Figure 2. Peat stratigraphy in Eipurs bog.
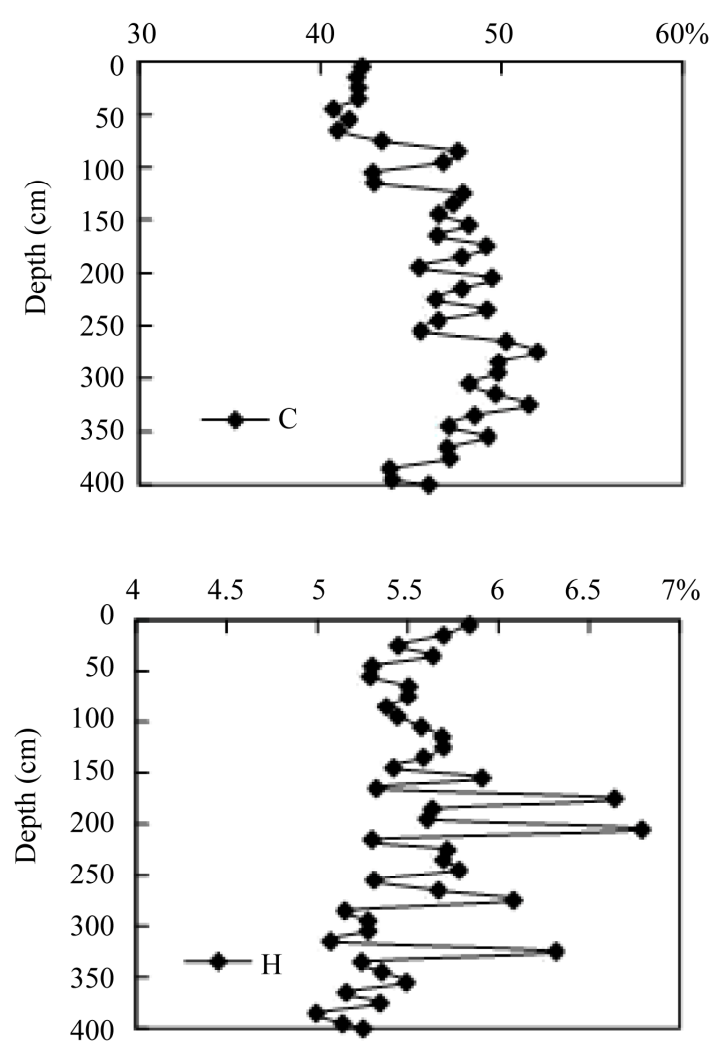

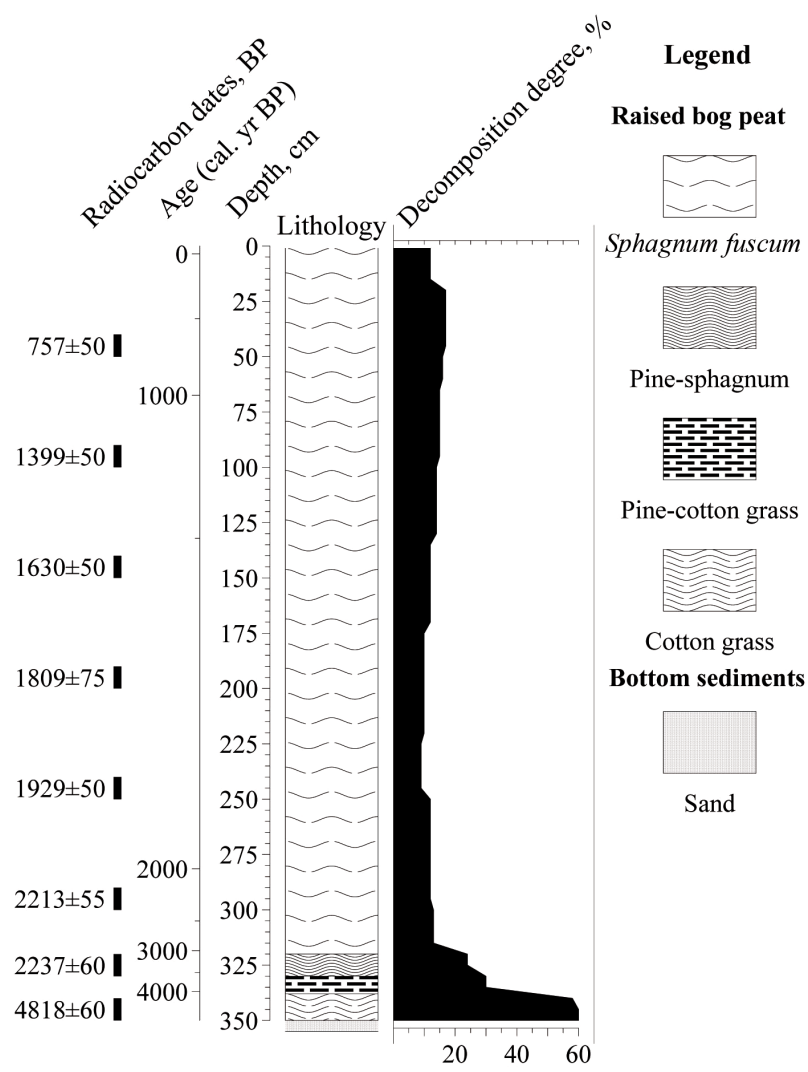

Figure 3. Peat stratigraphy in Dzelve bog.
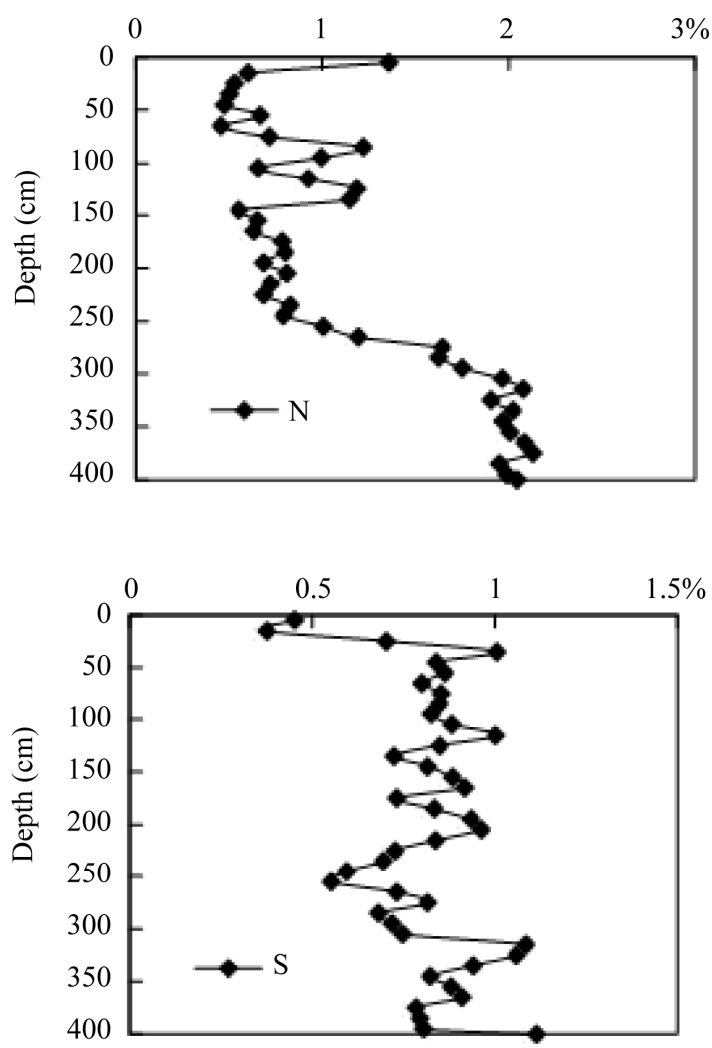

Figure 4. Elemental composition of peat in Eipurs bog. 
Table 1. Peat decomposition degree and elemental composition of peat in Dzelve bog.

\begin{tabular}{cccccccccc}
\hline Depth, cm & Decomposition, $\%$ & $\mathrm{C} \%$ & $\mathrm{H} \%$ & $\mathrm{~N} \%$ & $\mathrm{~S} \%$ & $\mathrm{O} / \mathrm{C}$ & $\mathrm{H} / \mathrm{C}$ & $\mathrm{N} / \mathrm{C}$ \\
\hline 5 & 12 & 44.77 & 5.91 & 0.73 & 0.89 & 0.80 & 1.58 & 0.014 \\
105 & 14 & 45.68 & 5.78 & 0.53 & 0.88 & 0.77 & 1.52 & 0.010 \\
160 & 12 & 46.05 & 5.81 & 0.55 & 0.88 & 0.76 & 1.51 & 0.010 \\
205 & 10 & 45.53 & 5.60 & 0.47 & 0.81 & 0.78 & 1.47 & 0.009 \\
240 & 9 & 44.84 & 5.47 & 0.45 & 0.88 & 0.81 & 1.46 & 0.009 \\
305 & 13 & 47.42 & 5.75 & 0.76 & 0.87 & 0.72 & 1.45 & 0.014 \\
320 & 12 & 45.73 & 5.55 & 0.62 & 1.22 & 0.77 & 1.45 & 0.012 \\
325 & 24 & 44.73 & 5.44 & 0.60 & 0.64 & 0.82 & 1.46 & 0.012 \\
335 & 30 & 52.10 & 5.20 & 1.51 & 0.73 & 0.58 & 1.20 & 0.025 \\
340 & 38 & 52.70 & 5.20 & 1.70 & 0.77 & 0.56 & 1.18 & 0.028 \\
350 & $>60$ & 55.53 & 6.20 & 1.23 & 1.19 & 0.48 & 1.34 & 0.019 \\
\hline
\end{tabular}

demonstrate a significantly higher variability. Changes in $\mathrm{N}$ concentrations (increased in the upper and lower horizons of the bog, and also demonstrating increased values coinciding with the changes in the peat composition and formation conditions) could be associated with changes in the peat botanical composition and decomposition degree. S concentrations are significantly lower just in a few upper centimeters of the peat bog and comparatively stable along the peat column. At the same time, the elemental composition (Table 1) of Dzelve Bog is very much different, and it largely reflects the peat column composition: $\mathrm{C}$ content in the upper layers is much lower $(\sim 45 \%)$ and comparatively uniform up to the depth of $3.25 \mathrm{~m}$; then, it rapidly increases, reaching $55 \%$ for highly decomposed peat.

The elemental ratio (Table 1, Figure 5) is much more informative than the elemental composition of peat. N/C ratio can be considered as a good indicator of the humification process at first due to specific microbial activity in the anaerobic, acidic environment and enrichment of the peat mass with nitrogen-containing compounds of bacterial origin [7]. This ratio can be efficiently used as a measure of peat degradation. The decreasing N/C ratios indicate increasing peat decomposition (due to microbial decay) and vice versa. $\mathrm{H} / \mathrm{C}$ ratio is an index of molecular complexity (and also of aromaticity), and it ranges from 1.6 to 1.2 [13]. It is relatively constant with depth; below $50 \mathrm{~cm}$, it decreases. $\mathrm{O} / \mathrm{C}$ ratio, for its part, is considered as an indicator of carbohydrate and carboxylic group contents and can be directly related to aromatization of the peat-forming organic matter [13]. $\mathrm{O} / \mathrm{C}$ ratio decreases with depth; however, the values of this indicator are high in the layers with higher decomposition degrees.

$\mathrm{H} / \mathrm{C}$ and $\mathrm{O} / \mathrm{C}$ values are rather fluctuating around the average values common for peat and do not reflect high variability of peat decomposition and high diversity (Figure 2) of precursor living biota. N/C ratio in general increases with the depth of the peat core, and this ratio is high in the upper layer (possibly due to the presence of proteinaceous materials of living organic matter). Significant fluctuations follow with increasing depth (starting from $250 \mathrm{~cm}$ ). After that, the values of N/C ratio increase again for more decomposed peat layers. This finding demonstrates that the atomic ratio is only of a limited value for study of the humification process due to the significant impact of the original plant composition and peat formation conditions.

The data of elemental analysis can also be used for calculating the hydrogen deficiency $\phi$ and oxidation degree $\omega$ indexes [17]. However, in this case, these indexes have only weak relations with the high variability of peat properties in the peat core of Eipurs Bog, and the peat hydrogen deficiency $\phi$ and the degree of oxidation $\omega$ can be considered as relatively homogeneous (Figure 6) within studied peat profiles.

\subsection{Peat Humification Character}

Studying the transformation (humification) of living organic material is of utmost importance for better understanding of carbon biogeochemical cycling. From this perspective, studies of peat diagenesis within profiles and identification of correlations among peat properties (age, decomposition degree, botanical composition, elemental and functional composition), peat humification and properties of humic acids isolated from peat are needed. Such studies can help describe the process of humification at a molecular level, supporting the development of new knowledge of chemical and biochemical processes behind humification. Following this approach, in this study, we selected two ombrotrophic bogs of a similar age, located spatially close to each other (Figure 1), but with very much differing peat column stratigraphy (Figures 2, 3), bog profile botanical composition as well as decomposition degree Thus, the selected study objects are suitable for analyzing the relations between peat 

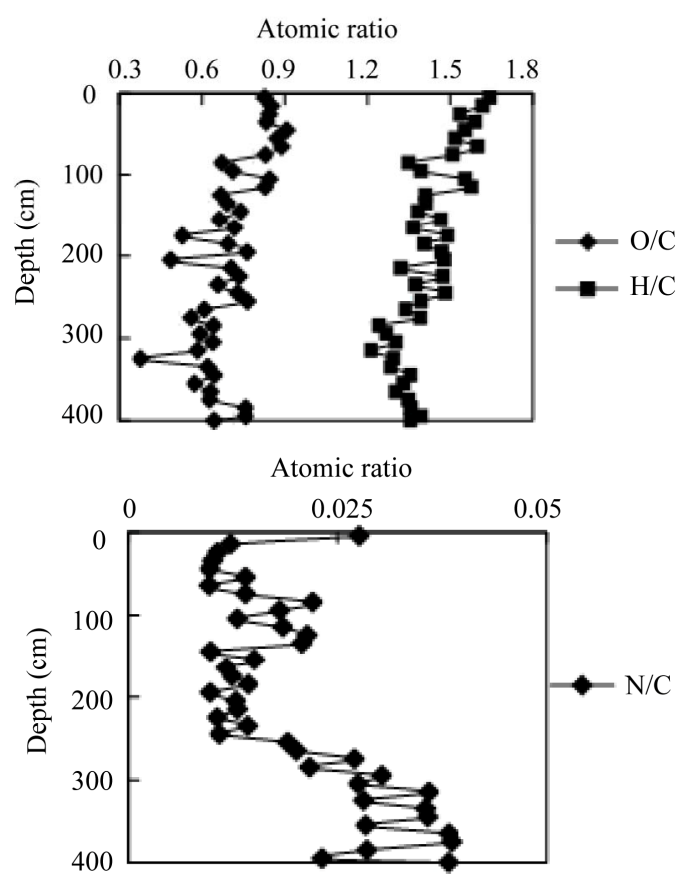

Figure 5. Element ratio in peat from Eipurs bog.

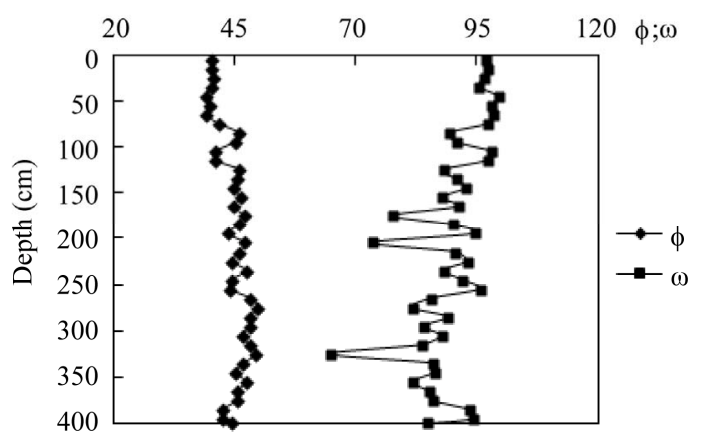

Figure 6. Changes of the index of hydrogen deficiency $\phi$ and degree of oxidation $\omega$ in peat from Eipurs bog.

formation conditions and peat properties as well as for identifying the humification indicators, best describing the living organic material transformation process.

Absorption at $540 \mathrm{~nm}$ in the visible spectra of peat alkaline extracts can be used as a simple indicator of humification process, as suggested and recently improved by [20]. As it can be seen from Figure 7, this humification index demonstrates expected differences when used for describing Dzelve and Eipurs Bogs, and the changes can be associated with both the peat decomposition degree and the differences in peat composition. In order to provide reliable quantitative information about the diagenesis of peat, we carried out further studies on the dependence of parameters describing peat humification (age and depth of the studied peat layer, decomposition, $\mathrm{HA} / \mathrm{FA}, \mathrm{D}_{540}, \mathrm{E}_{4} / \mathrm{E}_{6}$ and $\left.\mathrm{I}_{460} / \mathrm{I}_{510}\right)$ on parameters describing peat composition $(\mathrm{O} / \mathrm{C}, \mathrm{H} / \mathrm{C}, \mathrm{N} / \mathrm{C}$ ) (Figure 8, Tables

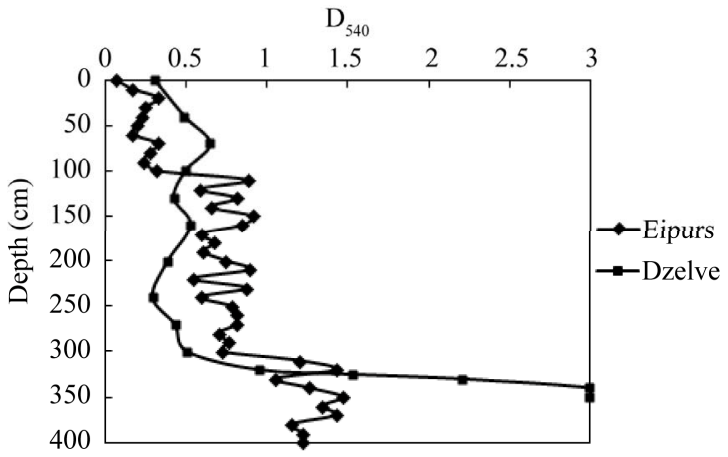

Figure 7. Changes of humification index (adsorption of peat extract at $540 \mathrm{~nm}$ ) versus depth in peat from Dzelve and Eipurs bogs.

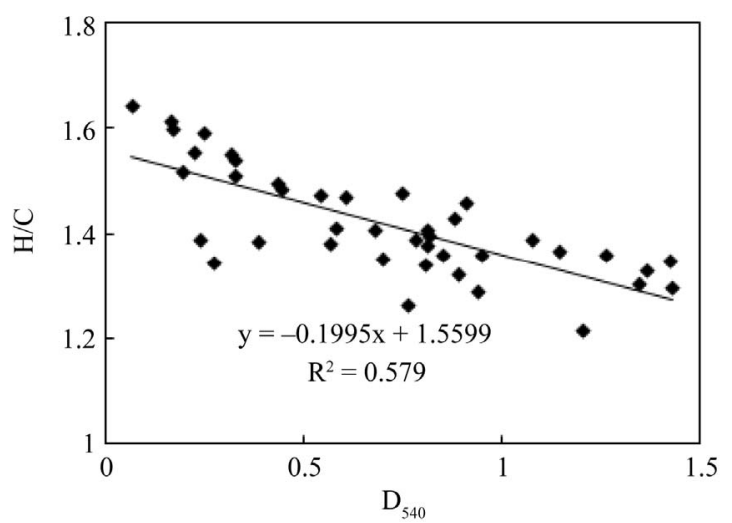

Figure 8. Correlation between peat decomposition (\%, Eipurs and Dzelve bogs), elemental ratio of peat $\mathrm{H} / \mathrm{C}$ and $\mathbf{D}_{540}$.

2, 3). These relations slightly differ in the studied bogs. In general, the found correlations allow to identify the parameters most suitable for characterization of the process of transformation of living organic matter into peat organic matter.

As it can be seen from Figure 8, the parameter describing peat composition (atomic ratio $\mathrm{H} / \mathrm{C}$ ) is well correlated with the peat decomposition degree, thus indicating molecular mechanisms behind peat humification dehydrogenation (hydrogen removal from organic molecules) during humification process.

The humification index describing basic changes in the properties of peat is well correlated with the elemental ratios in the peat cores, thus depicting changes in peat organic materials during humification of living organic matter. Other indicators of peat organic matter, generally well describing peat transformation process, include $\mathrm{HA} /$ FA, $\mathrm{D}_{540}, \mathrm{E}_{4} / \mathrm{E}_{6}$, whereas $\mathrm{I}_{460} / \mathrm{I}_{510}$ describes not so much peat than humic matter properties (Tables 2, 3).

The UV-Vis absorption ratios were measured to provide information about the humification of peat samples. The ratio $\mathrm{E}_{4} / \mathrm{E}_{6}$ is often used to describe the extent of 
Table 2. Correlations between indicators describing decomposition of the precursor living materials (age and depth of the studied peat layer, decomposition, $\mathrm{HA} / \mathrm{FA}, \mathrm{D}_{540}, \mathbf{E}_{4} / \mathbf{E}_{6}$ and $\left.\mathrm{I}_{460} / \mathrm{I}_{510}\right)$ and peat composition parameters $(\mathrm{O} / \mathrm{C}, \mathrm{H} / \mathrm{C}, \mathrm{N} / \mathrm{C})$ in Eipurs bog.

\begin{tabular}{|c|c|c|c|c|c|c|c|c|}
\hline & $\mathrm{O} / \mathrm{C}$ & $\mathrm{H} / \mathrm{C}$ & $\mathrm{N} / \mathrm{C}$ & Age, ${ }^{14} \mathrm{C}$ years & $\mathrm{E}_{4} / \mathrm{E}_{6}$ & $\mathrm{I}_{460} / \mathrm{I}_{510}$ & $\mathrm{HA} / \mathrm{FA}$ & $\mathrm{D}_{540}$ \\
\hline Decomposition, $\%$ & 0.585 & 0.616 & 0.626 & 0.575 & 0.055 & 0.330 & 0.437 & 0.860 \\
\hline Depth, cm & 0.517 & 0.588 & 0.624 & 0.858 & 0.175 & 0.393 & 0.201 & 0.794 \\
\hline $\mathrm{O} / \mathrm{C}$ & & 0.667 & 0.487 & 0.292 & 0.051 & 0.568 & 0.474 & 0.543 \\
\hline $\mathrm{H} / \mathrm{C}$ & & & 0.582 & 0.476 & 0.008 & 0.555 & 0.543 & 0.592 \\
\hline $\mathrm{N} / \mathrm{C}$ & & & & 0.636 & 0.242 & 0.387 & 0.578 & 0.667 \\
\hline Age,,${ }^{14} \mathrm{C}$ years & & & & & 0.313 & 0.250 & 0.323 & 0.741 \\
\hline $\mathrm{E}_{4} / \mathrm{E}_{6}$ & & & & & & 0.239 & 0.260 & 0.664 \\
\hline $\mathrm{I}_{460} / \mathrm{I}_{510}$ & & & & & & & 0.843 & 0.857 \\
\hline HA/FA & & & & & & & & 0.776 \\
\hline
\end{tabular}

Significance level $\mathrm{p}=0.05$.

Table 3. Correlations between indicators describing decomposition of the precursor living materials (age and depth of the studied peat layer, decomposition, $\mathrm{HA} / \mathrm{FA}, \mathrm{D}_{540}, \mathbf{E}_{4} / \mathbf{E}_{6}$ and $\left.\mathbf{I}_{460} / \mathbf{I}_{510}\right)$ and peat composition parameters $(\mathbf{O} / \mathrm{C}, \mathrm{H} / \mathrm{C}, \mathrm{N} / \mathrm{C})$ in Dzelve bog.

\begin{tabular}{|c|c|c|c|c|c|c|c|c|}
\hline & $\mathrm{O} / \mathrm{C}$ & $\mathrm{H} / \mathrm{C}$ & $\mathrm{N} / \mathrm{C}$ & Age, ${ }^{14} \mathrm{C}$ years & $\mathrm{E}_{4} / \mathrm{E}_{6}$ & $\mathrm{I}_{460} / \mathrm{I}_{510}$ & $\mathrm{HA} / \mathrm{FA}$ & $\mathrm{D}_{540}$ \\
\hline Decomposition, \% & 0.587 & 0.689 & 0.469 & 0.871 & 0.525 & 0.466 & 0.458 & 0.792 \\
\hline Depth, cm & 0.318 & 0.525 & 0.226 & 0.700 & 0.304 & 0.159 & 0.201 & 0.461 \\
\hline $\mathrm{O} / \mathrm{C}$ & & 0.668 & 0.705 & 0.786 & 0.574 & 0.768 & 0.642 & 0.785 \\
\hline $\mathrm{H} / \mathrm{C}$ & & & 0.804 & 0.738 & 0.495 & 0.520 & 0.538 & 0.735 \\
\hline $\mathrm{N} / \mathrm{C}$ & & & & 0.491 & 0.419 & 0.610 & 0.638 & 0.720 \\
\hline Age,,${ }^{14} \mathrm{C}$ years & & & & & 0.695 & 0.632 & 0.578 & 0.813 \\
\hline $\mathrm{E}_{4} / \mathrm{E}_{6}$ & & & & & & 0.774 & 0.859 & 0.694 \\
\hline $\mathrm{I}_{460} / \mathrm{I}_{510}$ & & & & & & & 0.865 & 0.817 \\
\hline $\mathrm{HA} / \mathrm{FA}$ & & & & & & & & 0.732 \\
\hline
\end{tabular}

Significance level $\mathrm{p}=0.05$.

condensation of the aromatic C-containing structures: low ratios reflect high degrees of condensation of aromatics, while high ratios mean the presence of large quantities of aliphatic structures and low amounts of condensed aromatics [23]. This ratio is also inversely related to the degree of aromaticity, particle size, molecular weight and acidity [24]. In the present study, the variability of the $\mathrm{E}_{4} / \mathrm{E}_{6}$ ratios in the peat profiles was generally low (Tables 2, 3).

\subsection{Elemental Composition and Functional Characteristics of Peat Humic Acids}

Studying the elemental composition of peat HAs extracted from a peat column can give information about ongoing humification reactions during peat development. Humification recently has been mostly studied with the aim to analyze the composting and soil formation processes. However, the humification process in peat is much different from that in composts and soils, where decomposition of organic matter is quite rapid in early humification stages. In contrast to that, in waterlogged environments, under the impact of anaerobic and acidic conditions, the humification process in the saturated peat layers is very much retarded. Therefore, in peat it is possible to follow the humification process for very long periods (thousands of years).

There were significant variations in the elemental composition of HAs within peat profiles. Depending on the bog and the intervals of changes, the elemental compositions of the studied peat HAs (Figure 9) were highly variable: $\mathrm{C}$ was $42.74 \%$ - 59.49\%; $\mathrm{H}$ was $3.98 \%-5.41 \%$, $\mathrm{N}$ was $1.80 \%-2.79 \%$, S was $0.23 \%-1.71 \%$ and ash was $0.34 \%-1.46 \%$. The $\mathrm{O}$ content, which was within the range of $32.52 \%-48.78 \%$, was determined by mass balance. In general, whereas the concentrations of $\mathrm{C}$ and $\mathrm{H}$ increased with depth, the concentrations of $\mathrm{N}$ decreased with depth, and the concentration of S was very variable 


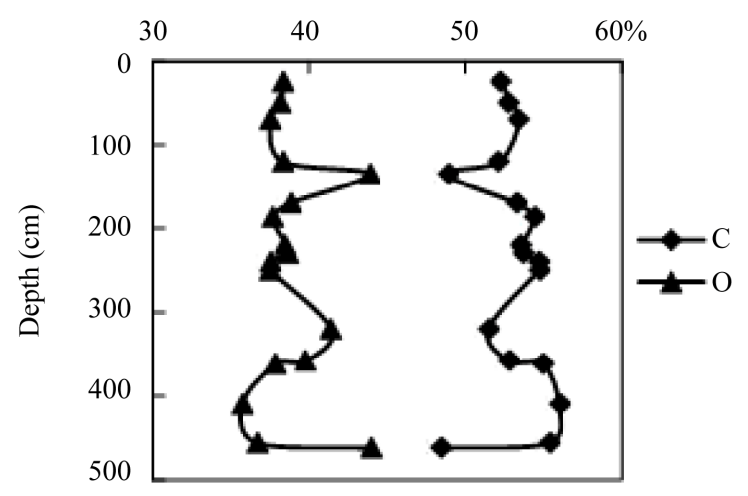

(a)

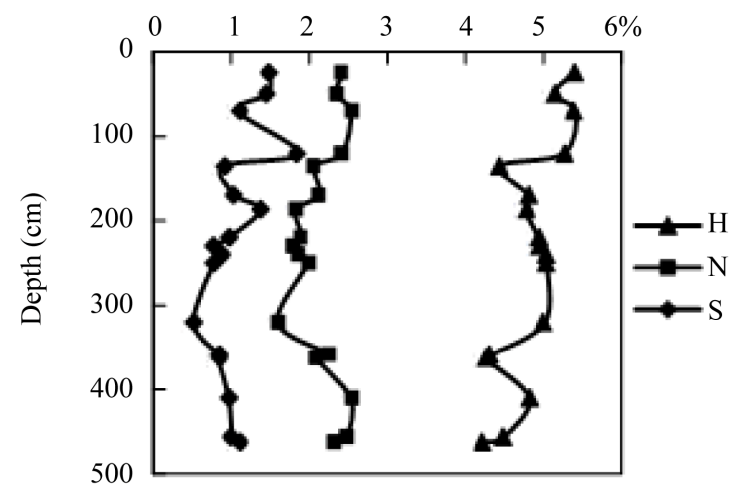

(c)

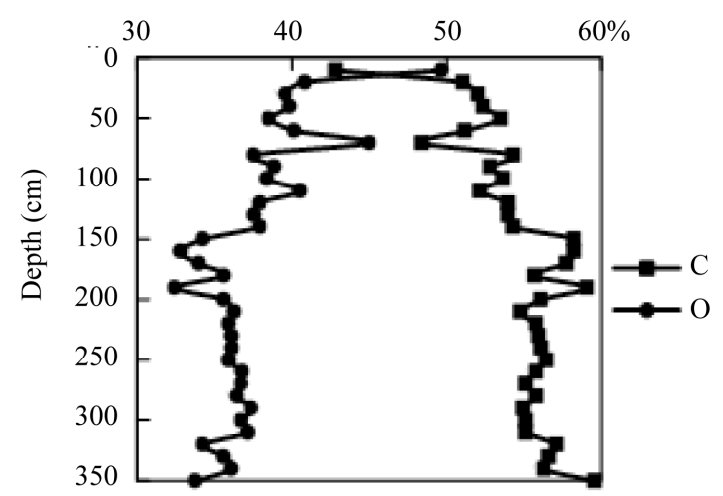

(b)

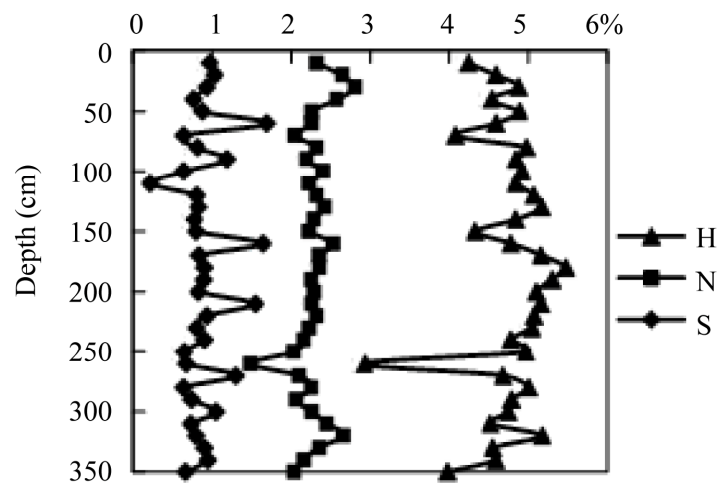

(d)

Figure 9. Elemental composition of peat humic acids from Eipurs (a, c) and Dzelve (b, d) bog.

throughout the profile. The elemental composition of HAs from peat in Latvia is of similar magnitude to those for peat HAs from other regions of the world [12,13, 25-27].

Changes in the main atomic ratios $(\mathrm{H} / \mathrm{C}, \mathrm{N} / \mathrm{C}$ and $\mathrm{O} / \mathrm{C})$ within peat humic acid profiles are described in Figure 10, and the $\mathrm{O} / \mathrm{C}$ vs. N/C atomic ratios indicate that the decarboxylation processes were in line with the reduction of $\mathrm{N}$ concentration relative to $\mathrm{C}$ content in HAs.

Changes of the $\mathrm{H} / \mathrm{C}$ ratio in humic acids from Dzelve Bog shows the importance of peat accumulation rate.

The bottom to middle bog layers show an increasing $\mathrm{H} / \mathrm{C}$ ratio. The upper layers of humic acids from Dzelve Bog shows a relatively stable $\mathrm{H} / \mathrm{C}$ ratio, a relatively high amount of carbon and hydrogen, and a decreasing oxygen percentage.

Changes of the $\mathrm{H} / \mathrm{C}$ ratios in humic acids from Eipurs Bog show differences between fen peat at the 3.5 - 4.62 $\mathrm{m}$ depth and other layers of bog, and these values are lower for fen peat. Lower $\mathrm{C}, \mathrm{H}$ percentage and $\mathrm{H} / \mathrm{C}$ ratio and higher $\mathrm{O} / \mathrm{C}$ ratio are common for peat which is fully or partly formed from wood (generally-pine). These effects indicate the presence of lignin. At the same time, wooden peat usually is better decomposed.

The relation between the $\mathrm{H} / \mathrm{C}$ and $\mathrm{O} / \mathrm{C}$ atomic ratios (Figure 11) of HAs (van Krevelen graphs are frequently applied for studies of HSs and the $\mathrm{C}$ biogeochemical cy- cle) [29] reveals changes in the elemental composition of humic acids, and thus is useful in identification of structural changes and the degree of maturity of HAs. Figure $\mathbf{1 1}$ can be considered as a graphical representation of the humification process, indicating the degree of maturity and the intensity of degradation processes, such as dehydrogenation (reduction of $\mathrm{H} / \mathrm{C}$ ratio), decarboxylation (reduction of $\mathrm{O} / \mathrm{C}$ ratio) and demethylation occurring during the genesis of humic acids. From the point of view of chemistry, the elemental ratio of peat HAs demonstrate changes in HA composition during peat diagenesis, considering it as a process in which more labile structures (carbohydrates, amino acids, etc) are destroyed, while thermodynamically more stable aromatic and polyaromatic structures emerge. Comparatively, the studied peat HAs are at the start of the transformation process of living organic matter.

To provide reliable and quantitative information about the diagenesis of HAs, we carried out further studies of the dependence of the elemental composition of peat and its humic acids on the peat age (depth and decomposition degree) (Figure 12).

The trends of dependence between $\mathrm{H} / \mathrm{C}$ values and the depth of the peat samples were mostly negatively related, demonstrating that dehydrogenation is amongst the dominant processes during ageing of peat HAs.

A study of correlations between the properties of hu- 


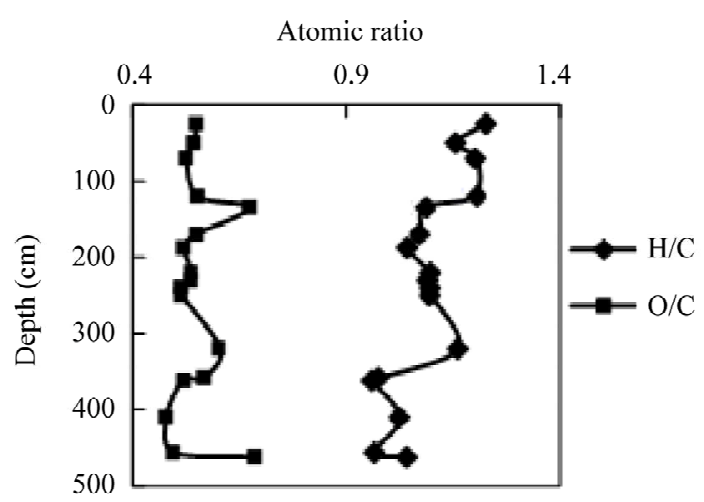

(a)

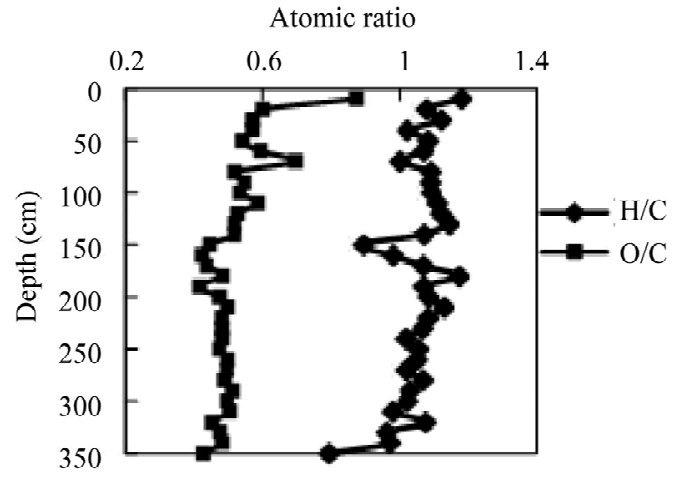

(c)

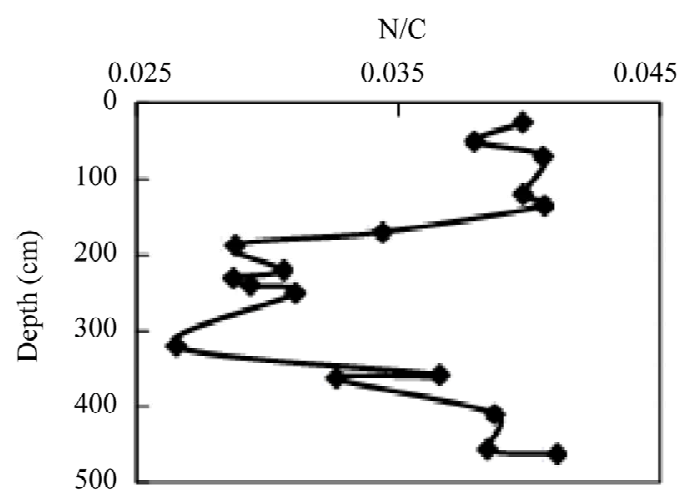

(b)

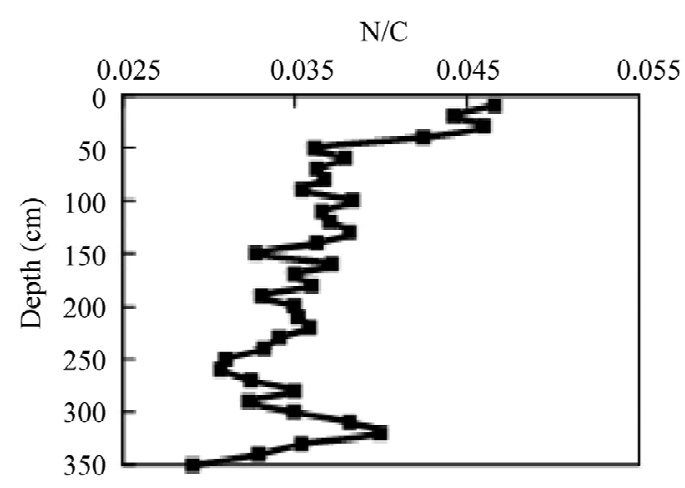

(d)

Figure 10. Element ratios in peat humic acids from Eipurs (a, b) and Dzelve (c, d) bogs.

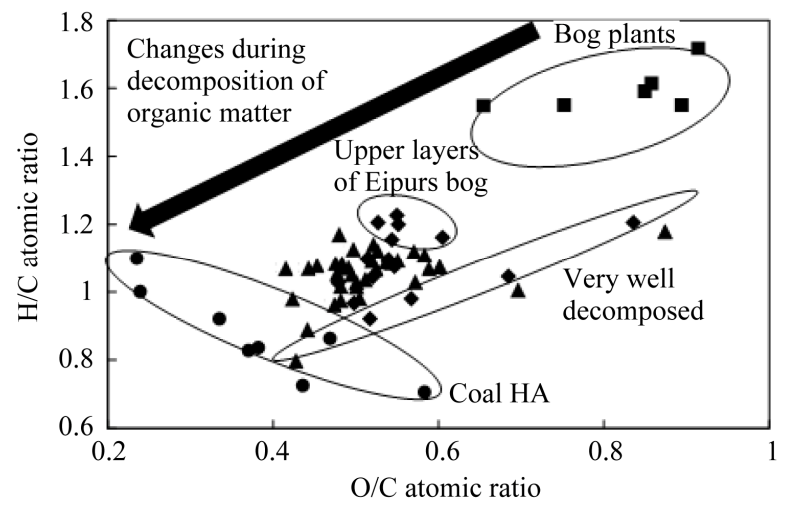

Figure 11. Van Krevelen (H/C vs. O/C atomic ratio) graph of peat humic acids from Eipurs $(\diamond)$ and Dzelve $(\Delta)$ bogs, bog plants (ש) [28], coal HA (•) [28].

mic acids isolated from corresponding peat layers and peat decomposition degree proves the concept about major processes behind the humification and illustrates the diagenesis of peat organic matter (Figure 13).

At first, the increased peat decomposition degree might be associated with the dehydrogenation of peat humic acids, probably leading towards the development of aromatic structures. Another evidently ongoing process is the development of acidity-genesis of carboxylic groups in peat humic substances during peat organic matter de-

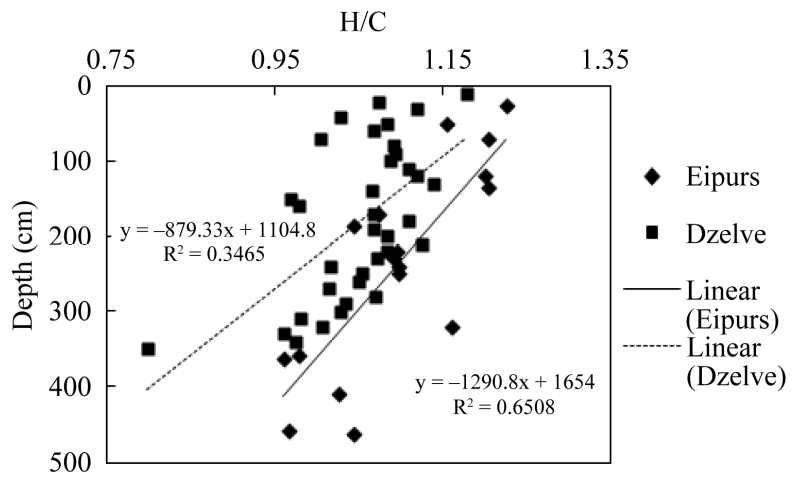

Figure 12. Correlation between peat depth and $\mathrm{H} / \mathrm{C}$ atomic ratio of peat humic acids.

composition and humification.

\section{Conclusion}

A study of correlations between the properties of humic acids isolated from corresponding peat layers and peat decomposition degree proves the concept about major processes behind the humification and illustrates the diagenesis of peat organic matter (Figure 13). At first, the increased peat decomposition degree might be associated with the dehydrogenation of peat humic acids, probably leading towards the development of aromatic structures. 

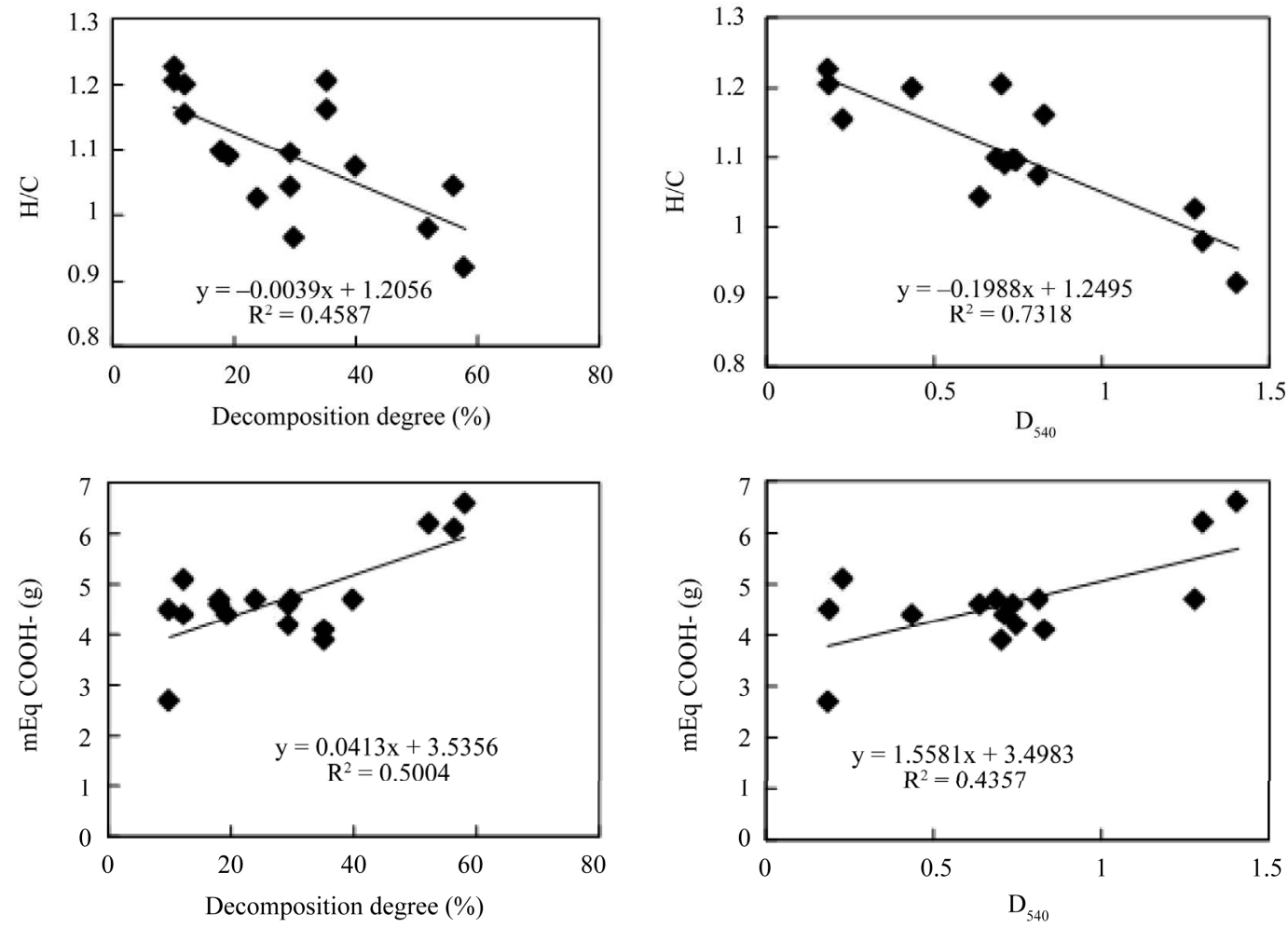

Figure 13. Correlation among the properties of humic acid and peat decomposition degree, and $D_{540}$ of Eipurs bog.

Another evidently ongoing process is the development of acidity - genesis of carboxylic groups in peat humic substances during peat organic matter decomposition and humification.

\section{REFERENCES}

[1] O. Francioso, C. Ciavatta, D. Montecchio, V. Tugnoli, S. Sanchez-Cortes and C. Gessa, "Quantitative Estimation of Peat, Brown Coal and Lignite Humic Acids Using Chemical Parameters, 1H-NMR and DTA Analyses," Bioresource Technology, Vol. 88, No. 3, 2003, pp. 189-195. doi:10.1016/S0960-8524(03)00004-X

[2] R. A. Houghton, "The Contemporary Carbon Cycle," In: K. K. Turekian and H. D. Holland, Eds., Treatise on Geochemistry, Vol. 8, 2003, Elsevier, Dordrecht, pp. 473513. doi:10.1016/B0-08-043751-6/08168-8

[3] C. Cocozza, V. D’Orazio, T. M. Miano and W. Shotyk, "Characterization of Solid and Aqueous Phases of a Peat Bog Profile Using Molecular Fluorescence Spectroscopy, ESR and FT-IR, and Comparison with Physical Properties," Organic Geochemistry, Vol. 34, No. 1, 2003, pp. 49-60. doi:10.1016/S0146-6380(02)00208-5

[4] D. Yeloff and D. Mauquoy, "The Influence of Vegetation Composition on Peat Humification: Implications for Paleoclimatic Studies," Boreas, Vol. 35, No. 4, 2006, pp. 662-673. doi:10.1111/j.1502-3885.2006.tb01172.x

[5] C. Zaccone, T. M. Miano and W. Shotyk, "Qualitative Comparison between Raw Peat and Related Humic Acids in an Ombrotrophic Bog Profile," Organic Geochemistry, Vol. 38, No. 1, 2007, pp. 151-160. doi:10.1016/j.orggeochem.2006.06.023

[6] P. Falkowski, R. J. Scholes, E. Boyle, J. Canadell, D. Canfield, J. Elser, N. Gruber, K. Hibbard, P. Hogberg, S. Linder, F. T. Mackenzie, B. Moore, T. Pedersen, Y. Rosenthal and K. H. Tan, "Humic Matter in Soil and the Environment: Principles and Controversies," Marcel Dekker, New York, 2003.

[7] A. Borgmark, "Holocene Climate Variability and Periodicities in South-Central Sweden, as Interpreted from Peat Humification Analysis," Holocene, Vol. 15, No. 3, 2005, pp. 387-395. doi:10.1191/0959683605hl816rp

[8] R. A. Ghaly, J. B. Pyke, A. E. Ghaly and V. I. Ugursal, "Remediation of Diesel-Oil-Contaminated Soil Using Peat, Energy Sources, A: Recovery, Utilization, and Environmental Effects," Chemosphere, Vol. 21, 1999, pp. 785-799.

[9] P. A. Brown, S. A. Gill and S. J. Allen, "Metal Removal from Wastewater Using Peat," Water Resources, Vol. 34, 2000, pp. 3907-3916.

[10] C. J. Caseldine, A. Baker, D. J. Charman and D. Hendon, "A Comparative Study of Optical Properties of $\mathrm{NaOH}$ Peat Extracts: Implications for Humification Studies," Holocene, Vol. 10, No. 5, 2000, pp. 649-658. doi:10.1191/095968300672976760

[11] S. J. Chapman, C. D. Campbell, A. R. Fraser and G. Puri, "FTIR Spectroscopy of Peat in and Bordering Scots Pine Woodland: Relationship with Chemical and Biological 
Properties," Soil Biology and Biochemistry, Vol. 33, No. 9, 2001, pp. 1193-1200. doi:10.1016/S0038-0717(01)00023-2

[12] C. Zaccone, C. Cocozza, A. K. Cheburkin, W. Shotyk and T. M. Miano, "Enrichment and Depletion of Major and Trace Elements, and Radionuclides in Ombrotrophic Raw Peat and Corresponding Humic Acids," Geoderma, Vol. 141, No. 3-4, 2007, pp. 235-246. doi:10.1016/j.geoderma.2007.06.007

[13] H. Anderson and A. Hepburn, "Variation of Humic Substances within Peat Profile," In: C. H. Fuchsman, Ed., Peat and Water, Academic Press, New York, 1986, pp. 177-194.

[14] C. Zaccone, C. Cocozza, A. K. Cheburkin, W. Shotyk and T. M. Miano, "Distribution of As, Cr, Ni, Rb, Ti and $\mathrm{Zr}$ between Peat and Its Humic Fraction along an Undisturbed Ombrotrophic Bog Profile (NW Switzerland)," Applied Geochemistry, Vol. 23, No. 1, 2008, pp. 25-33. doi:10.1016/j.apgeochem.2007.09.002

[15] I. I. Lishtvan and N. T. Korol, "Basic Properties of Peat and Methods for Their Determination," Nauka I Teknika, Minsk, 1975 (in Russian).

[16] K. H. Tan, "Soil Sampling, Preparation, and Analysis," Second Edition, Taylor \& Francis Group, New York, 2005.

[17] S. S. Fong and M. Mohamed, "Chemical Characterization of Humic Substances Occurring in the Peats of Sarawak, Malaysia," Organic Geochemistry, Vol. 38, No. 6, 2007, pp. 967-976. doi:10.1016/j.orggeochem.2006.12.010

[18] Y. Chen, N. Senesi and M. Schnitzer, "Information Provided on Humic Substances by $\mathrm{E}_{4} / \mathrm{E}_{6}$ Ratios," Soil Science Society of America Journal, Vol. 41, No. 2, 1977, pp. 352-358. doi:10.2136/sssaj1977.03615995004100020037x

[19] J. J. Blackford and F. M. Chambers, "Determining the Degree of Peat Decomposition for Peat-Based Paleoclimatic Studies," International Peat Journal, Vol. 5, 1993, pp. 7-24.

[20] A. Borgmark, "The Colour of Climate: Changes in Peat Decomposition as a Proxy for Climate Change-A Study of Raised Bogs in South-central Sweden," PhD Thesis, Stockholm University, Stockholm, 2005.
[21] A. G. Zavarzina, V. V. Demin, T. I. Nifanteva, V. M. Shkinev, T. V. Danilova and B. Y. Spivakov, "Extraction of Humic Acids and Their Fractions in Poly(ethylene glycol)-Based Aqueous Biphasic Systems," Analytica Chimica Acta, Vol. 452, No. 1, 2002, pp. 95-103. doi:10.1016/S0003-2670(01)01428-3

[22] D. M. B. P. Milori, L. M. Neto, C. Bayer, J. Mielniczuk and V. S. Bagnato, "Humification Degree of Soil Humic Acids Determined by Fluorescence Spectroscopy," Soil Science, Vol. 167, No. 1, 2002, pp. 739-749. doi:10.1097/00010694-200211000-00004

[23] Y. Chin, G. R. Aiken and K. M. Danielsen, "Binding of Pyrene to Aquatic and Commercial Humic Substances: The Role of Molecular Weight and Aromaticity," Environmental Science and Technology, Vol. 31, No. 6, 1997, pp. 1630-1635. doi:10.1021/es960404k

[24] C. S. Uyguner, C. Hellriegel, W. Otto and C. K. Larive, "Characterization of Humic Substances: Implications for Trihalomethane Formation," Analytical and Bioanalytical Chemistry, Vol. 378, No. 6, 2004, pp. 1579-1586. doi:10.1007/s00216-003-2451-7

[25] T. Qiamg, S. Xiaoquan and N. Zheming, "Comparative Characteristic Studies on Soil and Commercial Humic Acids," Fresenius Journal of Analytical Chemistry, Vol. 347, No. 8-9, 1993, pp. 330-336. doi:10.1007/BF00323816

[26] T. Yamaguchi, H. Hayashi, Y. Yazawa, M. Uomori, F. Yazaki and N. N. Bambalov, "Comparison of Basic Characteristics of Humic Acids Extracted from Peats and Other Sources," International Peat Journal, Vol. 8, 1998, pp. 87-94.

[27] E. Garnier-Sillam, S. Hariyento and Y. Bourezgui, "Humic Substances in Peats," Analysis, Vol. 27, No. 5, 1999, pp. 405-408. doi:10.1051/analusis:1999270405

[28] J. Š̄ire, M. Kḷaviņš, O. Purmalis and V. Melecis, "Experimental Study of Peat Humification Indicators," Proceedings of Latvian Academy of Sciences, B, Vol. 62, No. 1-2, 2008, pp. 18-27.

[29] D. W. Van Krevelen, "Graphical-Statistical Method for the Study of Structure and Reaction Processes of Coal," Fuel, Vol. 29, 1950, pp. 269-228. 